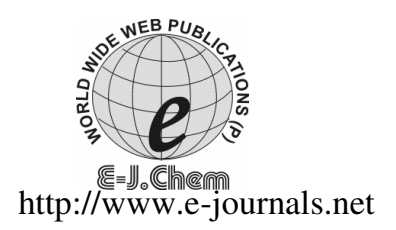

ISSN: 0973-4945; CODEN ECJHAO

E-Journal of Chemistry

2011, 8(3), 1174-1179

\title{
Biological Important Ni(II) Ternary Complexes Derived from 2-Substituted Benzothiazoles and Amino Acids
}

\author{
NARENDRA PAL, MAHESH KUMAR and GITA SETH* \\ Department of Chemistry, University of Rajasthan, Jaipur, India \\ gita_seth@yahoo.co.in
}

Received 7 October 2010; Accepted 16 December 2010

\begin{abstract}
Biological important ternary complexes of the type $[\mathrm{NiCl}(\mathrm{L}-\mathrm{L})$ $\left.(\mathrm{A}-\mathrm{A})\left(\mathrm{H}_{2} \mathrm{O}\right)\right]$ and $\left[\mathrm{Ni}\left(\mathrm{L}^{-\mathrm{L}^{\prime}}\right)(\mathrm{A}-\mathrm{A})\left(\mathrm{H}_{2} \mathrm{O}\right)_{2}\right]$, where $\mathrm{A}-\mathrm{A}=$ Glycine $($ Gly), Alanine (Ala), L-L = 2-(2'-aminophenyl)benzothiazole (APBT) and $\mathrm{L}^{\prime} \mathrm{L}^{\prime}=2-\left(2^{\prime}-\right.$ hydroxyphenyl)benzothiazole (HPBT), 2-(2'-mercaptophenyl)benzothiazole (MPBT) have been synthesized. These complexes have been characterized by elemental analysis, molecular weight determination, conductivity, magnetic measurements, infrared, electronic spectral and TGA studies. On the basis of above described studies an octahedral geometry has been suggested for these complexes. All these complexes are coloured, thermally stable, monomeric and non-electrolytic in nature. The ligands and their metal complexes were tested against pathogenic fungi Aspergillus niger and Fusarium oxysporum to assess their fungicidal properties, the antifungal activity data reveals that these metal complexes are found more fungitoxic than the parent ligands.
\end{abstract}

Keywords: Benzothiazole, Spectral studies, Amino acids, Antifungal activity.

\section{Introduction}

Compounds with a benzothiazole moiety have received considerable attention because of their widespread occurrence in biologically active molecules such as antitumor, antimaleria, fungicide, anti-HIV, antiviral and analgesic agents ${ }^{1.3}$. Recently, radiolabeling of benzothiazole derivatives have been developed for PET imaging in the detection of alzheimer diseases ${ }^{4}$. These compounds also have many industrial applications; for example some 2-substitued benzothiazole are utilized as fluorescence agents in textile dyeing, antioxidants and valcanization accelerators of rubber.

A large number of benzimidazole derivative have been synthesized and patented as fungicide ${ }^{5.6}$. The formation and structural aspects of some transition metal complexes of 2-substituted benzimidazole derivatives have been reported by Seth et al. ${ }^{7}$ and various other 
workers $^{8,9}$. We describe here the synthesis, characterization and biological activity of $\mathrm{Ni}(\mathrm{II})$ ternary complexes derived from 2-substituted benzothiazole viz. 2-(2'-aminophenyl)benzothiazole (APBT), 2-(2'-hydroxyphenyl)benzothiazole (HPBT), 2-(2'-mercaptophenyl)benzothiazole (MPBT) and amino acids viz. glycine (Gly) and alanine (Ala) ligands. As the biological activity is often augmented when a ligand form complexes. The resulting mixed ligand complexes may be of potential biological importance. The structure of ligands used to synthesize the $\mathrm{Ni}$ (II) ternary complexes are shown in Figure 1 and 2.<smiles>[X]c1ccccc1-c1nc2ccccc2s1</smiles><smiles>NC(N)C(=O)O</smiles>

\begin{tabular}{c|ccc} 
& APBT & HPBT & MPBT \\
\hline $\mathrm{x}$ & $\mathrm{NH}$ & $\mathrm{O}$ & $\mathrm{S}$
\end{tabular}

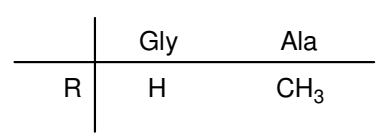

Figure 1. Structure of the ligands APBT, HPBT, MPBT, Gly and Ala

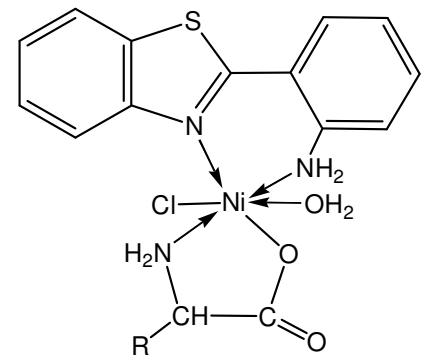

Where $\mathrm{X}=\mathrm{O}, \mathrm{SR}=\mathrm{H}, \mathrm{CH}_{3}$<smiles>[X]c1ccccc1C1=NN(C)c2ccccc2S1</smiles>

Figure 2. The suggested chemical structures of the $\mathrm{Ni}(\mathrm{II})$ ternary complexes

\section{Experimental}

All the solvents were distilled prior to use, $o$-aminothiophenol, anthranilic acid, salicylic acid, thiosalicylic acid, $\mathrm{NiCl}_{2} \cdot 6 \mathrm{H}_{2} \mathrm{O}$ were purchased from Merck and used as such.

\section{Physical measurements}

Microanalysis was carried out at the CDRI Lucknow, India. Melting points were determined on a capillary melting point apparatus and are uncorrected, IR spectra were recorded (with $\mathrm{KBr}$ pellets) on a SHIMADZU 8400 SPIR spectrophotometer. Electronic spectra were recorded on a Varian-Cary UV-visible spectrometer. Magnetic moments were measured on a Gouy balance. Molar conductance were measured in $10^{-3} \mathrm{M}$ DMF on a Systronics conductivity bridge model 305 . Molecular weights were determined by the Rast camphor method. Nitrogen was determined by the Kjeldahl's method and sulfur was estimated by the Messenger's method. Chloride was determined by the Volhard's method. nickel was estimated gravimetrically ${ }^{19}$.

\section{Synthesis of 2-substituted benzothiazoles (APBT, HPBT, MPBT)}

The 2-substituted benzothiazoles viz. 2-(2'-aminophenyl) benzothiazole (APBT), 2-(2'-hydroxyphenyl) benzothiazole (HPBT), 2-(2'-marceptophenyl)benzothiazole (MPBT) 
were prepared by condensation $o$-aminothiophenol $(1.25 \mathrm{~g}, 0.01 \mathrm{~mol})$ with anthranilic acid $(1.37 \mathrm{~g}, 0.01 \mathrm{~mol})$, salicylic acid $(1.38 \mathrm{~g}, 0.01 \mathrm{~mol})$ and thiosalicylic acid $(1.54 \mathrm{~g}, 0.01 \mathrm{~mol})$ in polyphosphoric acid $(20 \mathrm{~mL})$ using the method reported in literature ${ }^{20}$. The reaction mixture was heated to $250^{\circ} \mathrm{C}$ under reflux with constant stirring for $4 \mathrm{~h}$. The temperature was brought down to $100{ }^{\circ} \mathrm{C}$ and the contents were poured into a large volume of rapidly stirred water. The resultant slurry was made alkaline with $50 \% \mathrm{NaOH}$. The crude product was collected by filtration and washed with sufficient amount of water, dried in vacuo and recrystallized from ethanol.

\section{Preparation of nickel(II) ternary complex}

To a solution of $\mathrm{NiCl}_{2} .6 \mathrm{H}_{2} \mathrm{O}(0.95 \mathrm{~g}, 0.004 \mathrm{~mol})$ in dry EtOH $(25 \mathrm{~mL})$ was added APBT $(0.90 \mathrm{~g}, 0.004 \mathrm{~mol}) / \mathrm{HPBT}(0.91 \mathrm{~g}, 0.004 \mathrm{~mol}) / \mathrm{MPBT}(0.97 \mathrm{~g}, 0.004 \mathrm{~mol})$ and glycine $(0.30 \mathrm{~g}, 0.004 \mathrm{~mol}) /$ alanine $(0.36 \mathrm{~g}, 0.004 \mathrm{~mol})$ in dry EtOH $(25 \mathrm{~mL})$. The reaction mixture was then refluxed in the presence of a drop of pyridine with constant stirring for $4 \mathrm{~h}$, and allowed to stand at room temperature overnight. These were filtered, recrystallized from EtOH and dried in vacuo.

\section{Results and Discussion}

The Ni(II) ternary complexes were synthesized by $\mathrm{NiCl}_{2} \cdot 6 \mathrm{H}_{2} \mathrm{O}$ with 2-substituted benzothiazoles (APBT, HPBT and MPBT) and amino acids (Gly, Ala) in 1:1:1 molar ratio.

Where

$$
\begin{aligned}
\mathrm{NiCl}_{2} \cdot 6 \mathrm{H}_{2} \mathrm{O}+(\mathrm{L}-\mathrm{L})+(\mathrm{A}-\mathrm{A}) \stackrel{\text { Ethanol }}{\stackrel{\text { Reflux }}{\longrightarrow}}\left[\mathrm{NiCl}(\mathrm{L}-\mathrm{L})(\mathrm{A}-\mathrm{A})\left(\mathrm{H}_{2} \mathrm{O}\right)\right] \\
\mathrm{NiCl}_{2} \cdot 6 \mathrm{H}_{2} \mathrm{O}+\left(\mathrm{L}^{-\mathrm{L}^{\prime}}\right)+(\mathrm{A}-\mathrm{A}) \stackrel{\text { Ethanol }}{\stackrel{\text { Reflux }}{\longrightarrow}}\left[\mathrm{Ni}\left(\mathrm{L}^{-L^{\prime}}\right)(\mathrm{A}-\mathrm{A})\left(\mathrm{H}_{2} \mathrm{O}\right)_{2}\right]
\end{aligned}
$$

$$
\mathrm{L}-\mathrm{L}=\mathrm{APBT}, \mathrm{L}-\mathrm{L}^{\prime}=\mathrm{HPBT}, \mathrm{MPBT} \text { and A-A = Gly, Ala }
$$

These reactions are processed easily and lead to the formation of coloured solids, which are stable to air and moisture. The resulting Ni(II) ternary complexes are soluble in DMSO and DMF. The molar conductance values of $10^{-3} \mathrm{M}$ solutions of these complexes lay in the range 10-20 $\Omega^{-1} \mathrm{~cm}^{2} \mathrm{~mol}^{-1}$ in dry DMF, indicating their non-electrolytic behaviour ${ }^{10}$. The monomeric nature of these complexes has been confirmed by the molecular weight determination. The analytical data and physical properties of the ligands and their Ni(II) ternary complexes are given in Table 1 . The compounds were characterized on the basis of following studies.

\section{Infrared spectra}

The important IR spectral bands and their tentative assignments are presented in Table 2. The ligands APBT, HPBT, MPBT, Gly and Ala act as bidentate ligands in these $\mathrm{Ni}(\mathrm{II})$ ternary complexes using nitrogen, oxygen and sulfur as donor atoms. The IR spectra of APBT, Gly/Ala shows two strong bands in the region $3400-3370 \mathrm{~cm}^{-1}$ and $3310-3250 \mathrm{~cm}^{-1}$ due to $v_{\text {as }}(\mathrm{N}-\mathrm{H})$ and $v_{\mathrm{s}}(\mathrm{N}-\mathrm{H})$ vibrations of $\mathrm{NH}_{2}$ of these ligands, respectively. These bands are shifted to lower frequency by $35-80 \mathrm{~cm}^{-1}$ in the respective $\mathrm{Ni}$ (II) ternary complexes, suggesting the coordination through nitrogen lone pair of the $\mathrm{NH}_{2}$ group to the $\mathrm{Ni}$ atom without any deprotanation ${ }^{11}$. It is further supported by appearance of the new bands in the region $436-432 \mathrm{~cm}^{-1}$ due to $v(\mathrm{Ni} \leftarrow \mathrm{N})$ vibration. The appearance of absorption bands in the region $448-445 \mathrm{~cm}^{-1}$ may be assigned to $v(\mathrm{Ni}-\mathrm{O})$ vibration. The occurrence of non-ligand absorption band in the region $320-315 \mathrm{~cm}^{-1}$ may be attributed to $v(\mathrm{Ni}-\mathrm{Cl})$ vibration ${ }^{12}$. 
Table 1. The analytical data and physical properties of the ligands and their Ni(II) ternary complexes

\begin{tabular}{|c|c|c|c|c|c|c|c|c|}
\hline \multirow{2}{*}{$\begin{array}{l}\text { Compound and } \\
\text { empirical formula }\end{array}$} & \multirow{2}{*}{ Colour } & \multirow{2}{*}{$\begin{array}{ll}0 & 0 \\
0 & 0 \\
0 & 0 \\
\vdots & \vdots\end{array}$} & \multicolumn{5}{|c|}{ Elemental analysis found (calcd.) $\%$} & \multirow{2}{*}{$\begin{array}{l}\text { Molecular } \\
\text { weight } \\
\text { found } \\
\text { (calcd.) }\end{array}$} \\
\hline & & & $\mathrm{H}$ & $\mathrm{N}$ & $\mathrm{S}$ & $\mathrm{Cl}$ & $\mathrm{Ni}$ & \\
\hline $\begin{array}{c}{[\mathrm{NiCl}(\mathrm{APBT})(\mathrm{Gly})} \\
\left.\left(\mathrm{H}_{2} \mathrm{O}\right)\right] \mathrm{NiC}_{15} \mathrm{H}_{16} \mathrm{O}_{3} \mathrm{~N}_{3} \mathrm{SCl}\end{array}$ & $\begin{array}{l}\text { Bluish } \\
\text { Green }\end{array}$ & 60225 & $\begin{array}{cc}43.58 & 3.87 \\
(43.67)(3.91)\end{array}$ & $\begin{array}{c}10.12 \\
(10.18)\end{array}$ & $\begin{array}{c}7.70 \\
(7.77)\end{array}$ & $\begin{array}{c}8.50 \\
(8.59)\end{array}$ & $\begin{array}{c}14.18 \\
(14.23)\end{array}$ & \\
\hline 2. $\begin{array}{c}{\left[\mathrm{NiCl}(\mathrm{APBT})(\mathrm{Ala})\left(\mathrm{H}_{2} \mathrm{O}\right)\right]} \\
\mathrm{NiC}_{16} \mathrm{H}_{18} \mathrm{O}_{3} \mathrm{~N}_{3} \mathrm{SCl}\end{array}$ & $\begin{array}{l}\text { Bluish } \\
\text { Green }\end{array}$ & 62230 & $\begin{array}{cc}44.95 & 4.18 \\
(45.05)(4.25)\end{array}$ & $\begin{array}{c}9.72 \\
(9.85)\end{array}$ & $\begin{array}{c}7.42 \\
(7.52)\end{array}$ & $\begin{array}{c}8.22 \\
(8.31)\end{array}$ & $\begin{array}{c}13.65 \\
(13.76)\end{array}$ & \\
\hline $\begin{array}{c}{[\mathrm{Ni}(\mathrm{MPBT})(\mathrm{Gly})} \\
\text { 3. } \\
\left.\left(\mathrm{H}_{2} \mathrm{O}\right)_{2}\right] \mathrm{NiC}_{15} \mathrm{H}_{16} \mathrm{O}_{4} \mathrm{~N}_{2} \mathrm{~S}_{2}\end{array}$ & $\begin{array}{l}\text { Yellowish } \\
\text { Green }\end{array}$ & 61240 & $\begin{array}{cc}43.71 & 3.85 \\
(43.82) & (3.92)\end{array}$ & $\begin{array}{c}6.71 \\
(6.81)\end{array}$ & $\begin{array}{c}15.52 \\
(15.60)\end{array}$ & 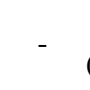 & $\begin{array}{c}14.22 \\
(14.28)\end{array}$ & $\begin{array}{c}409.10 \\
(411.15)\end{array}$ \\
\hline 4. $\begin{array}{c}{[\mathrm{Ni}(\mathrm{MPBT})(\mathrm{Ala})} \\
\left.\left(\mathrm{H}_{2} \mathrm{O}\right)_{2}\right] \mathrm{NiC}_{16} \mathrm{H}_{18} \mathrm{O}_{4} \mathrm{~N}_{2} \mathrm{~S}_{2}\end{array}$ & $\begin{array}{l}\text { Light } \\
\text { Green }\end{array}$ & 6524 & $\begin{array}{cc}45.12 & 4.18 \\
(45.20) & (4.27)\end{array}$ & $\begin{array}{c}6.48 \\
(6.59)\end{array}$ & $\begin{array}{c}15.01 \\
(15.08)\end{array}$ & - & $\begin{array}{c}13.70 \\
(13.81)\end{array}$ & $\begin{array}{c}422.02 \\
(425.18)\end{array}$ \\
\hline 5. $\begin{array}{c}{[\mathrm{Ni}(\mathrm{HPBT})(\mathrm{Gly})} \\
\left.\left(\mathrm{H}_{2} \mathrm{O}\right)_{2}\right] \mathrm{NiC}_{15} \mathrm{H}_{16} \mathrm{O}_{5} \mathrm{~N}_{2} \mathrm{~S}\end{array}$ & $\begin{array}{l}\text { Light } \\
\text { Green }\end{array}$ & 6825 & $\begin{array}{cc}45.52 & 4.02 \\
(45.60) & (4.08)\end{array}$ & $\begin{array}{c}7.01 \\
(7.09)\end{array}$ & $\begin{array}{c}8.04 \\
(8.12)\end{array}$ & & $\begin{array}{c}14.75 \\
(14.86)\end{array}$ & $\begin{array}{c}392.50 \\
(395.08)\end{array}$ \\
\hline 6. $\begin{array}{c}{[\mathrm{Ni}(\mathrm{HPBT})(\mathrm{Ala})} \\
\left.\left(\mathrm{H}_{2} \mathrm{O}\right)_{2}\right] \mathrm{NiC}_{16} \mathrm{H}_{18} \mathrm{O}_{5} \mathrm{~N}_{2} \mathrm{~S}\end{array}$ & $\begin{array}{l}\text { Light } \\
\text { Green }\end{array}$ & 64262 & $\begin{array}{cc}46.92 & 4.36 \\
(46.98) & (4.43)\end{array}$ & $\begin{array}{c}6.78 \\
(6.85)\end{array}$ & $\begin{array}{c}7.77 \\
(7.84)\end{array}$ & 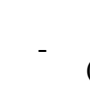 & $\begin{array}{c}14.27 \\
(14.35)\end{array}$ & $\begin{array}{c}406.02 \\
(409.11)\end{array}$ \\
\hline
\end{tabular}

Table 2. IR spectral data $\left(\mathrm{cm}^{-1}\right)$ of ligands (APBT, HPBT, MPBT) and Ni(II) ternary complexes

\begin{tabular}{|c|c|c|c|c|c|c|c|c|c|c|c|c|}
\hline $\begin{array}{l}\dot{0} \\
\dot{z} \\
\dot{s}\end{array}$ & Compound & $\begin{array}{c}v \\
(\mathrm{C}=\mathrm{C})\end{array}$ & $\begin{array}{c}v \\
(\mathrm{C}=\mathrm{N})\end{array}$ & $\frac{v(\mathrm{~N}}{\text { Asym. }}$ & $\begin{array}{l}\left.\mathrm{JH}_{2}\right) \\
\text { Sym. }\end{array}$ & $\begin{array}{c}v \\
(\mathrm{O}-\mathrm{H})\end{array}$ & $\begin{array}{c}v \\
(\mathrm{~S}-\mathrm{H}) \\
\end{array}$ & $\begin{array}{c}v \\
(\mathrm{C}=\mathrm{O})\end{array}$ & $\begin{array}{c}v \\
(\mathrm{Ni}-\mathrm{N})\end{array}$ & $\begin{array}{c}v \\
(\mathrm{Ni}-\mathrm{S})\end{array}$ & $\begin{array}{c}v \\
(\mathrm{Ni}-\mathrm{O}) \\
\end{array}$ & $\begin{array}{c}v \\
(\mathrm{Ni}-\mathrm{Cl})\end{array}$ \\
\hline 1. & APBT & 1586 & 1615 & 3370 & 3250 & - & - & - & - & - & - & - \\
\hline 2. & HPBT & 1590 & 1620 & - & - & 3330 & - & - & - & - & - & - \\
\hline 3. & MPBT & 1582 & 1618 & - & - & - & 2560 & - & - & - & - & - \\
\hline & $\begin{array}{c}{[\mathrm{NiCl}(\mathrm{APBT})} \\
\left.(\mathrm{Gly})\left(\mathrm{H}_{2} \mathrm{O}\right)\right]\end{array}$ & 1584 & 1608 & 3355 & 3240 & - & - & 1662 & 436 & - & 448 & 320 \\
\hline 5. & $\begin{array}{c}{[\mathrm{NiCl}(\mathrm{APBT})} \\
\left.(\mathrm{Ala})\left(\mathrm{H}_{2} \mathrm{O}\right)\right]\end{array}$ & 1580 & 1606 & 3352 & 3235 & - & - & 1660 & 432 & - & 445 & 315 \\
\hline 6. & $\begin{array}{c}{[\mathrm{Ni}(\mathrm{HPBT})} \\
\left.(\mathrm{Gly})\left(\mathrm{H}_{2} \mathrm{O}\right)_{2}\right]\end{array}$ & 1585 & 1612 & 3360 & 3242 & - & - & 1680 & 438 & - & 455 & - \\
\hline 7. & $\begin{array}{c}{[\mathrm{Ni}(\mathrm{HPBT})} \\
\left.(\mathrm{Ala})\left(\mathrm{H}_{2} \mathrm{O}\right)_{2}\right]\end{array}$ & 1582 & 1610 & 3358 & 3238 & - & - & 1675 & 435 & - & 452 & - \\
\hline 8. & $\begin{array}{c}{[\mathrm{Ni}(\mathrm{MPBT})} \\
\left.(\mathrm{Gly})\left(\mathrm{H}_{2} \mathrm{O}\right)_{2}\right]\end{array}$ & 1580 & 1606 & 3350 & 3230 & - & - & 1670 & 430 & 335 & 440 & - \\
\hline 9. & $\begin{array}{c}{[\mathrm{Ni}(\mathrm{MPBT})} \\
\left.(\mathrm{Ala})\left(\mathrm{H}_{2} \mathrm{O}\right)_{2}\right]\end{array}$ & 1578 & 1604 & 3348 & 3228 & - & - & 1665 & 428 & 332 & 438 & - \\
\hline
\end{tabular}

The broad band at $3330 \mathrm{~cm}^{-1}$ due to $v(\mathrm{O}-\mathrm{H})$ phenolic mode of HPBT, disappears in the $\mathrm{Ni}(\mathrm{II})$ ternary complexes, indicating the deprotonation of the $\mathrm{OH}$ group and coordination of phenolic oxygen to the $\mathrm{Ni}$ atom with the formation of $\mathrm{Ni}-\mathrm{O}$ bond. This gets further support by the appearance of bond in the region $455-452 \mathrm{~cm}^{-1}$ due to $v(\mathrm{Ni}-\mathrm{O})$ vibrations ${ }^{13}$. The IR spectrum of MPBT shows a band at $2560 \mathrm{~cm}^{-1}$ due to $v(\mathrm{~S}-\mathrm{H})$ (thiophenolic) vibration, which disappears in the $\mathrm{Ni}(\mathrm{II})$ ternary complexes, suggesting the deprotonation of -SH group and coordination through thiophenolic sulfur with the $\mathrm{Ni}$ atom. It is further supported by the appearance of new band in the region $335-332 \mathrm{~cm}^{-1}$ due to $v(\mathrm{Ni}-\mathrm{S})$ vibration. 
A medium or relatively weak band in the $1620-1615 \mathrm{~cm}^{-1}$ region in the IR spectra of the free ligands (APBT, HPBT and MPBT) is due to $v(\mathrm{C}=\mathrm{N})$ vibration. This band is shifted to lower frequency by $10-20 \mathrm{~cm}^{-1}$ in $\mathrm{Ni}$ (II) ternary complexes indicate the bonding of the benzothiazole tertiary nitrogen with $\mathrm{Ni}$ atom ${ }^{14}$. It is further confirmed by the appearance of band in the region $438-428 \mathrm{~cm}^{-1}$ due to $v(\mathrm{Ni} \leftarrow \mathrm{N})$ vibration.)

\section{Electronic absorption spectra and magnetic studies}

The electronic spectral data and magnetic moments of the Ni(II) ternary complexes are given in Table 3. The electronic spectra of $\mathrm{Ni}(\mathrm{II})$ ternary complexes were recorded in nujol mull. These complexes display three absorption band of low intensity due to d-d transitions in the region $9725-9830 \mathrm{~cm}^{-1}, 18225-18655 \mathrm{~cm}^{-1}$ and $28045-28245 \mathrm{~cm}^{-1}$ are assigned to the ${ }^{3} \mathrm{~A}_{2 \mathrm{~g}}(\mathrm{~F}) \rightarrow{ }^{3} \mathrm{~T}_{2 \mathrm{~g}}(\mathrm{~F})\left(v_{1}\right) ;{ }^{3} \mathrm{~A}_{2 \mathrm{~g}}(\mathrm{~F}) \rightarrow{ }^{3} \mathrm{~T}_{1 \mathrm{~g}}(\mathrm{~F})\left(v_{2}\right)$ and ${ }^{3} \mathrm{~A}_{2 \mathrm{~g}}(\mathrm{~F}) \rightarrow{ }^{3} \mathrm{~T}_{1 \mathrm{~g}}(\mathrm{P})\left(v_{3}\right)$ transition ${ }^{15}$, respectively. The position of these bands are similar to those reported for $\mathrm{Ni}$ (II) complexes with an octahedral geometry ${ }^{16}$. The room temperature magnetic moments of these complexes indicates the paramagnetic nature of the $\mathrm{Ni}$ (II) ion the magnetic moments of these complexes have been found in the range 3.26-3.32 B.M., which are in the consistent with the high spin state at the $\mathrm{Ni}(\mathrm{II})$ ion and in the range expected for octahedral complexes.

Table 3. Magnetic moments $\left(\mu_{\mathrm{B}}\right)$ and electronic spectral data for the Ni(II) ternary complexes of 2-substituted benzthiazole and amino acids

\begin{tabular}{|c|c|c|c|c|c|}
\hline \multirow[b]{2}{*}{ S.No. } & \multirow[b]{2}{*}{ Complex } & \multirow{2}{*}{$\begin{array}{c}\text { Magnetic } \\
\text { moment } \\
\left(\mu_{\mathrm{B}}\right) \text { B.M. }\end{array}$} & \multicolumn{3}{|c|}{ Electronic transition and assignments $\mathrm{cm}^{-}$} \\
\hline & & & $\begin{array}{c}{ }^{3} \mathrm{~A}_{2 \mathrm{~g}}(\mathrm{~F}) \rightarrow \\
{ }^{3} \mathrm{~T}_{2 \mathrm{~g}}(\mathrm{~F})\left(v_{1}\right)\end{array}$ & $\begin{array}{c}{ }^{3} \mathrm{~A}_{2 \mathrm{~g}}(\mathrm{~F}) \rightarrow \\
{ }^{3} \mathrm{~T}_{1 \mathrm{~g}}(\mathrm{~F})\left(v_{2}\right)\end{array}$ & $\begin{array}{l}{ }^{3} \mathrm{~A}_{2 \mathrm{~g}}(\mathrm{~F}) \rightarrow \\
{ }^{3} \mathrm{~T}_{1 \mathrm{~g}}(\mathrm{P})\left(v_{3}\right)\end{array}$ \\
\hline 1. & {$\left[\mathrm{NiCl}(\mathrm{APBT})(\mathrm{Gly})\left(\mathrm{H}_{2} \mathrm{O}\right)\right]$} & 3.30 & 9740 & 18250 & 28060 \\
\hline 2. & {$\left[\mathrm{NiCl}(\mathrm{APBT})(\mathrm{Ala})\left(\mathrm{H}_{2} \mathrm{O}\right)\right]$} & 3.32 & 9745 & 18255 & 28065 \\
\hline 3. & {$\left[\mathrm{Ni}(\mathrm{HPBT})(\mathrm{Gly})\left(\mathrm{H}_{2} \mathrm{O}\right)_{2}\right]$} & 3.26 & 9828 & 18650 & 28240 \\
\hline 4. & {$\left[\mathrm{Ni}(\mathrm{HPBT})(\mathrm{Ala})\left(\mathrm{H}_{2} \mathrm{O}\right)_{2}\right]$} & 3.27 & 9830 & 18655 & 28245 \\
\hline 5. & {$\left[\mathrm{Ni}(\mathrm{MPBT})(\mathrm{Gly})\left(\mathrm{H}_{2} \mathrm{O}\right)_{2}\right]$} & 3.26 & 9725 & 18225 & 28045 \\
\hline 6. & {$\left[\mathrm{Ni}(\mathrm{MPBT})(\mathrm{Ala})\left(\mathrm{H}_{2} \mathrm{O}\right)_{2}\right]$} & 3.27 & 9730 & 18230 & 28050 \\
\hline
\end{tabular}

TGA studies of $\mathrm{Ni}(\mathrm{II})$ ternary complexes

The existence of coordinated water molecule in these $\mathrm{Ni}$ (II) ternary complexes is confirmed by TGA studies. The coordinated water molecules are lost in the temperature range 100 to $310{ }^{\circ} \mathrm{C}$. The ultimate product of the thermal decomposition in these complex is nickel oxide. Thus, on the basis of analytical data and above describe studies, an octahedral geometry may be assigned for these $\mathrm{Ni}(\mathrm{II})$ ternary complexes.

The toxicity increased as the concentration was increased. The antifungal activity data also reveals that $\mathrm{Ni}(\mathrm{II})$ ternary complexes of MPBT and Gly/Ala are more fungitoxic than the complexes of APBT and $\mathrm{HPBT}^{18}$ ligands, respectively.

\section{Biological activity}

The antifungal activity of ligands (APBT, HPBT and MPBT) and their Ni(II) ternary complexes were carried out against pathogenic fungi, namely Aspergillus niger and Fusarium oxysporum by radial growth methods. The solution of the test compound were prepared (50, 100 and $200 \mathrm{ppm}$ ) in dimethylformamide. The linear growth of the fungus was recorded by measuring the diameter of the fungus colony after $72 \mathrm{~h}$ and the percentage inhibition was calculated as $100(\mathrm{C}-\mathrm{T}) / \mathrm{C}$, where $\mathrm{T}$ are the diameter of the fungus colony in the control and text plates respectively. The results of antifungal activity of the ligands and $\mathrm{Ni}$ (II) ternary complexes have been compared with the conventional fungicide Bavistin taken as standards (Table 4). 
Table 4. Fungicidal screening data for ligands (APBT, HPBT and MPBT) and their Ni(II) ternary complexes

\begin{tabular}{|c|c|c|c|c|c|c|}
\hline \multirow{4}{*}{ Complex } & \multicolumn{6}{|c|}{ Concentration, ppm } \\
\hline & \multirow{2}{*}{\multicolumn{3}{|c|}{$\begin{array}{c}\text { Aspergillus niger } \\
\text { Inhibition after } 72 \mathrm{~h}, \%\end{array}$}} & \multirow{2}{*}{\multicolumn{3}{|c|}{$\begin{array}{c}\text { Fusarium oxysporum } \\
\text { Inhibition after } 72 \mathrm{~h}, \%\end{array}$}} \\
\hline & & & & & & \\
\hline & 50 & 100 & 200 & 50 & 100 & 200 \\
\hline APBT & 40 & 52 & 62 & 43 & 55 & 64 \\
\hline HPBT & 34 & 46 & 58 & 36 & 48 & 60 \\
\hline MPBT & 46 & 58 & 68 & 48 & 61 & 70 \\
\hline$\left[\mathrm{NiCl}(\mathrm{APBT})(\mathrm{Gly})\left(\mathrm{H}_{2} \mathrm{O}\right)\right]$ & 62 & 74 & 88 & 65 & 78 & 90 \\
\hline$\left[\mathrm{NiCl}(\mathrm{APBT})(\mathrm{Ala})\left(\mathrm{H}_{2} \mathrm{O}\right)\right]$ & 63 & 75 & 89 & 66 & 79 & 92 \\
\hline$\left[\mathrm{Ni}(\mathrm{HPBT})(\mathrm{Gly})\left(\mathrm{H}_{2} \mathrm{O}\right)_{2}\right]$ & 52 & 68 & 78 & 54 & 70 & 80 \\
\hline$\left[\mathrm{Ni}(\mathrm{HPBT})(\mathrm{Ala})\left(\mathrm{H}_{2} \mathrm{O}\right)_{2}\right]$ & 53 & 69 & 80 & 55 & 71 & 82 \\
\hline$\left[\mathrm{Ni}(\mathrm{MPBT})(\mathrm{Gly})\left(\mathrm{H}_{2} \mathrm{O}\right)_{2}\right]$ & 72 & 85 & 94 & 73 & 87 & 96 \\
\hline$\left[\mathrm{Ni}(\mathrm{MPBT})(\mathrm{Ala})\left(\mathrm{H}_{2} \mathrm{O}\right)_{2}\right]$ & 73 & 86 & 96 & 74 & 88 & 98 \\
\hline Bavistin (Standard) & 86 & 98 & 100 & 87 & 99 & 100 \\
\hline
\end{tabular}

\section{References}

1. Hutchinson I, Jennings S A, Vishnuvajjala B R, Westwall A D and Stevens M F G, $J$ Med Chem., 2002, 45, 744-747.

2. Takasu K, Inoue H, Kim H S, Suzuki M, Shishido T, Wataya Y and Ihara M, J Med Chem., 2002, 45(5), 995-998.

3. Jeong C Y, Chio J and Yoon M H, Eur J Pharmacol., 2004, 502, 205.

4. Henriksen G, Yousefi B H, Drzezga A and Wester H J, Eur J Nucl Med Mol Imaging., 2008, 35, S75-S81.

5. Srivastava R S, J Indian Chem., 1990, 29A, 1024-1026.

6. Demir A S, Hamamci H, Sesenoglu O, Neslihanoglu R, Asikoglu B and Capanoglu D, Tetrahedron Lett., 2002, 43, 6447-6449.

7. Vyas P C, Yogesh, Chahar K, Yajula Garg and Gita Seth, J Indian Chem Soc., 2003, 80(9), 843-844.

8. Sbirna L S, Muresan V, Sbiren S and Muresani N, J Indian Chem Soc., 2005, 82, 389-392.

9. Bahri Ulkuseven and Aydin Tavman, Transition Met Chem., 2001, 26, 723-726.

10. Maurya R C, Mishra D D and Pillai S, Synth React Inorg Met Org Chem., 1997, 27, 1453.

11. Maurya R C and Sharma P, Indian J Chem., 1999, 38A, 509-513.

12. Khan T A, Synth React Inorg Met Org Chem., 2001, 31(6), 1023-1030.

13. Ibrahim K M, Bekheit M M and Abu El-Reash G M, Transition Met Chem., 1991, 16, 189.

14. Ulkuseven B and Tavman A, Trans Met Chem., 2001, 26, 723.

15. Shivakumaraiah and Gowda N M N, Indian J Chem., 2003, 42A, 1856-1860.

16. Carballo R, Castifieiras A, Hiller W and Strahle J, Polyhedron, 1993, 12, 1083.

17. Bamgboye T T and Bamgboye O A, Inorg Chem Acta, 1987, 133, 244.

18. Garoufis A, Hadjikakou S K and Coord N, Chem Rev., 2009, 253, 1384.

19. Vogel A I, A Text Book of Quantitative Inorganic Analysis, ELBS and Longmans, London, $6^{\text {th }}$ Ed., 1991.

20. Vyas P C, Ojha C K and Goyal A K, Chem Ind., 1980, 287; Heins D W, Alheim R J and Leavitt J J, J Am Chem Soc., 1957, 79, 427-429. 


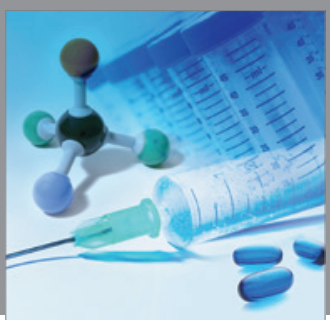

International Journal of

Medicinal Chemistry

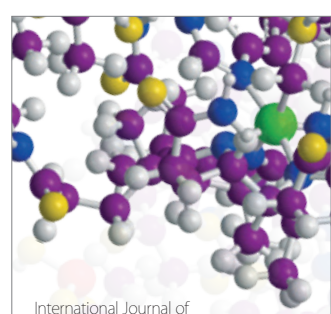

Carbohydrate Chemistry

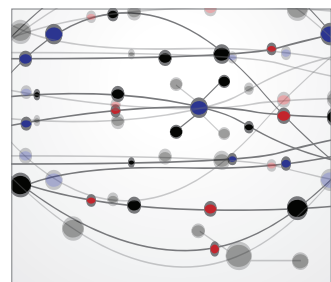

The Scientific World Journal
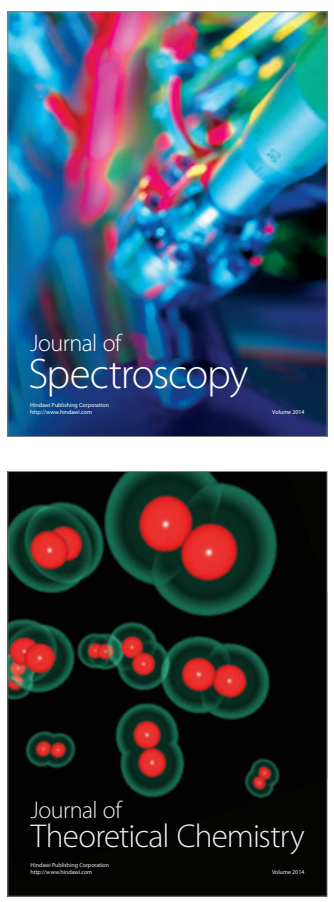
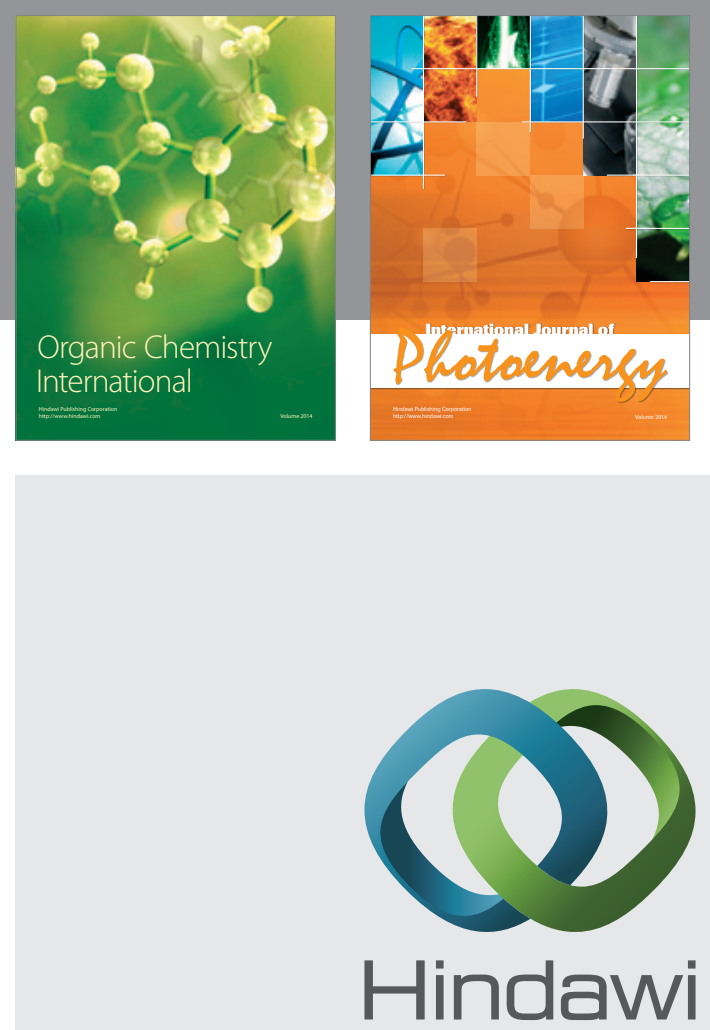

Submit your manuscripts at

http://www.hindawi.com
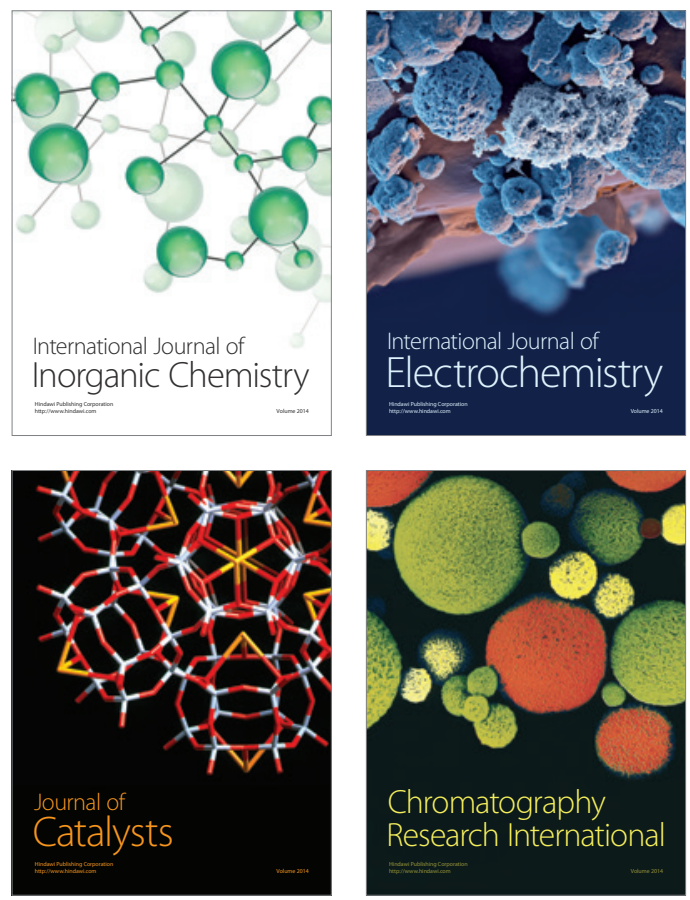
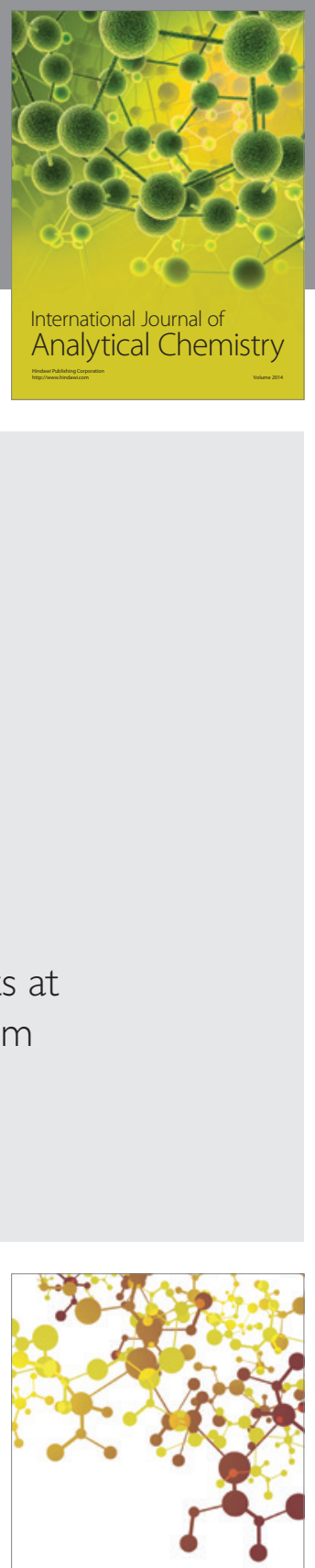

Journal of

Applied Chemistry
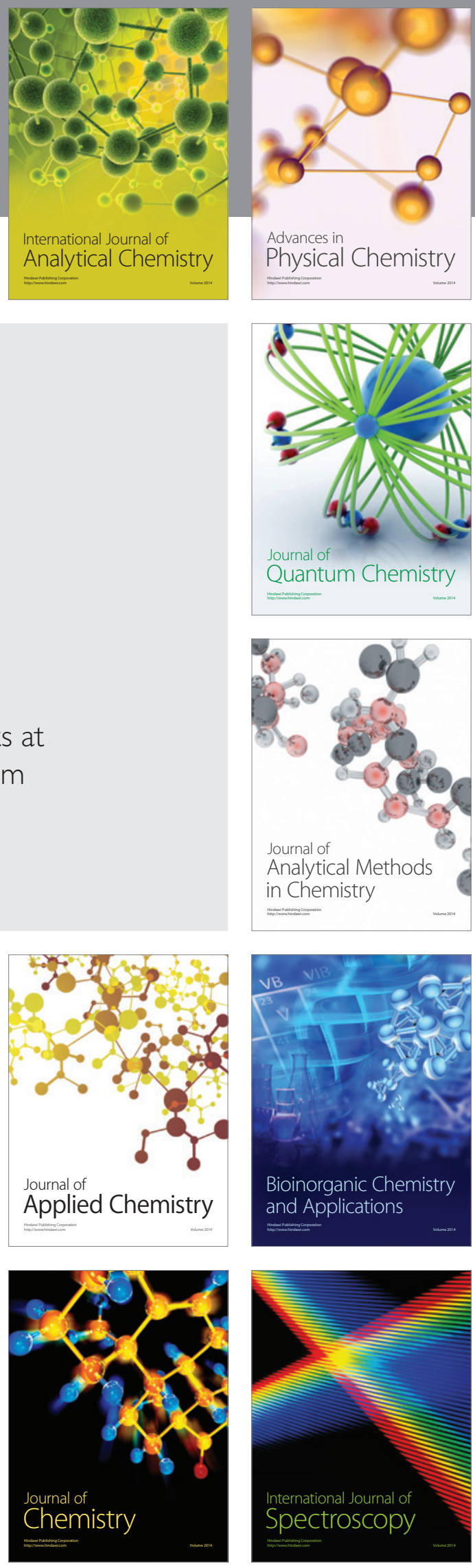